\title{
Assessment of the radiological impact and associated risk to non-human biota from routine liquid discharges of the Belgian nuclear power plants
}

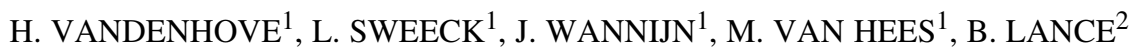

(Manuscript received 26 January 2012, accepted 13 March 2012)

\begin{abstract}
We performed an Environmental Risk Assessment (ERA) to evaluate the impact on non-human biota from liquid radioactive effluents discharged by the Belgian Nuclear Power Plants (NPPs) of Doel and Tihange. A deterministic risk assessment for aquatic and terrestrial ecosystems was performed using the ERICA tool and applying the ERICA screening value of $10 \mu \mathrm{Gy} \cdot \mathrm{h}^{-1}$. The ERA was performed for the radioactive discharge limits and for the actual releases (maxima and averages over the last 10 years, 1999-2008). All ERICA reference organisms were considered and depending on the assessment situation, additional reference organisms were included in the analysis. It can be concluded that the current discharge limits for the Belgian NPPs do not result in significant risks to the aquatic and terrestrial environment and that the actual discharges, which are a fraction of the liquid discharge limits, are unlikely to harm the environment.
\end{abstract}

Keywords: impact assessment / wildlife / radioactivity / releases / nuclear power plants

\section{Introduction}

The need for investigating potential risks induced by contaminants on non-human biota and ecosystems is now internationally recognized (ICRP, 2003, 2007; IAEA, 1992; UNSCEAR, 1996). Recommendations and guidelines on an international level and a comprehensive system to protect the environment from ionizing radiation are under development. As a consequence, a number of approaches/tools to estimate dose rates to non-human biota have been developed and some of them are being used in a regulatory context (Copplestone et al., 2001; US DOE, 2002). Initially, risk assessment focused exclusively on human health protection. Slowly, the demand for Ecological Risk Assessment (ERA) has extended to non-human

\footnotetext{
Belgian Nuclear Research Centre, Biosphere Impact Studies, 2400 Mol, Belgium.

2 Gdf-Suez, Electrabel Corporate Nuclear Safety Department, 1000 Brussels, Belgium.
} 
biota. As a consequence, ERA as a science has undergone considerable development in the last few decades, with guidelines being developed (Environment Canada, 1997; EC, 2003).

In view of the international changes regarding protection of non-human biota and possible future changes in national regulations, SCK $\bullet$ CEN was asked by GDFSUEZ to assess the exposure and associated environmental risk to non-human biota from routine radioactive releases from the Belgian Nuclear Power Plants. Fission and activation products released from nuclear power generating stations may be discharged into air or water. This study assesses the impact of radioactive liquid discharges (chemical component not studied) released into the Scheldt river in Doel and the Meuse river in Tihange on the present freshwater ecosystems and adjacent terrestrial ecosystems. The aim of this study is to evaluate if the limits established to protect humans are restrictive enough to also protect the environment and if actual liquid discharges do not hamper the environment.

\section{Approach}

\subsection{Problem formulation}

The first stage of any ERA is the problem formulation, which deals amongst others with the characterisation of the contaminant source term and the identification of potential ecological targets and the associated exposure pathways.

There are two NPP sites in Belgium, each with a capacity of about 3000 MWe: the Tihange NPP discharges into the Meuse river and the Doel NPP into the Scheldt river. The source term was defined based on discharge limits and annual discharge data (1999-2008). The discharge limits for Tihange and Doel are given in Table I. Since we require radionuclide specific concentrations for the evaluation of the environmental effects, we assumed for the Tihange discharge limits that all alpha activity consisted of ${ }^{241} \mathrm{Am}$, for its high internal dose conversion coefficient (DCC) (Vandenhove et al., 2009). ${ }^{110 \mathrm{~m}} \mathrm{Ag}$ is to resemble all 'other radionuclides' because it shows a high DCC and high biota transfer. For the NPP in Doel, annual liquid discharge limits are specified for tritium $\left(1.036 \times 10^{8} \mathrm{MBq}^{-1}\right)$ and

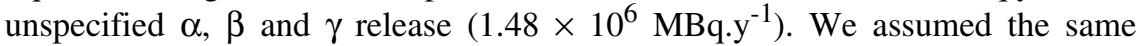
repartitioning as for Tihange in beta-gamma emitters and alpha-emitters. Only ${ }^{95} \mathrm{Nb}$, which is not detected in actual discharges of Doel (see Tab. II), was replaced by ${ }^{58} \mathrm{Co}$.

Many radionuclides were monitored in the liquid discharges but only for a number were relevant discharges obtained (though therefore not each year). For 
TABLE I

Annual liquid discharge limits for Tihange and Doel (MBq. $\left.\mathrm{y}^{-1}\right)$.

\begin{tabular}{|c|c|c|c|c|c|c|c|c|c|}
\hline \multirow[b]{2}{*}{ Tihange } & \multirow{2}{*}{$\begin{array}{c}\text { Tritium } \\
{ }^{3} \mathrm{H}\end{array}$} & \multicolumn{7}{|c|}{ Beta and gamma } & \multirow{2}{*}{$\begin{array}{l}\text { Alpha } \\
\left({ }^{241} \mathrm{Am}\right)\end{array}$} \\
\hline & & ${ }^{60} \mathrm{Co}$ & ${ }^{89} \mathrm{Sr}$ & ${ }^{90} \mathrm{Sr}$ & ${ }^{95} \mathrm{Nb}$ & ${ }^{134} \mathrm{Cs}$ & ${ }^{137} \mathrm{Cs}$ & $\begin{array}{c}\text { Others } \\
\left({ }^{110 \mathrm{~m}} \mathrm{Ag}\right)\end{array}$ & \\
\hline & $\begin{array}{r}1.48 \\
\times 10^{8}\end{array}$ & $\begin{array}{r}2.22 \\
\times 10^{5}\end{array}$ & $\begin{array}{c}2.78 \\
\times 10^{3(1)}\end{array}$ & $\begin{array}{c}2.78 \\
\times 10^{3(1)}\end{array}$ & $\begin{array}{r}1.11 \\
\times 10^{5}\end{array}$ & $\begin{array}{r}1.11 \\
\times 10^{5}\end{array}$ & $\begin{array}{r}1.11 \\
\times 10^{5}\end{array}$ & $\begin{array}{r}3.27 \\
\times 10^{5}\end{array}$ & $\begin{array}{r}2.22 \\
\times 10^{3}\end{array}$ \\
\hline Doel $^{(2)}$ & ${ }^{3} \mathrm{H}$ & ${ }^{60} \mathrm{Co}$ & ${ }^{89} \mathrm{Sr}$ & ${ }^{90} \mathrm{Sr}$ & ${ }^{58} \mathrm{Co}$ & ${ }^{134} \mathrm{Cs}$ & ${ }^{137} \mathrm{Cs}$ & $\begin{array}{l}\text { Others } \\
\left({ }^{110 \mathrm{~m}} \mathrm{Ag}\right)\end{array}$ & $\left({ }^{241} \mathrm{Am}\right)$ \\
\hline & $\begin{array}{r}1.04 \\
\times 10^{8}\end{array}$ & $\begin{array}{r}3.69 \\
\times 10^{5}\end{array}$ & $\begin{array}{c}4.6 \\
\times 10^{3}\end{array}$ & $\begin{array}{c}4.6 \\
\times 10^{3}\end{array}$ & $\begin{array}{r}1.85 \\
\times 10^{5}\end{array}$ & $\begin{array}{r}1.85 \\
\times 10^{5}\end{array}$ & $\begin{array}{r}1.85 \\
\times 10^{5}\end{array}$ & $\begin{array}{c}5.44 \\
\times 10^{5}\end{array}$ & $\begin{array}{r}3.70 \\
\times 10^{3}\end{array}$ \\
\hline
\end{tabular}

TABLE II

Annual actual discharges for Tihange and Doel (MBq.y $\left.\mathbf{y}^{-1}\right)$.

\begin{tabular}{|c|c|c|c|c|c|c|c|c|c|}
\hline Tihange & ${ }^{3} \mathrm{H}$ & ${ }^{134} \mathrm{Cs}$ & ${ }^{137} \mathrm{Cs}$ & ${ }^{55} \mathrm{Fe}$ & ${ }^{60} \mathrm{Co}$ & ${ }^{89} \mathrm{Sr}$ & ${ }^{90} \mathrm{Sr}$ & $95 \mathrm{Nb}$ & Others \\
\hline Average & $\begin{array}{c}4.7 \\
\times 10^{7}\end{array}$ & $\begin{array}{r}6.4 \\
\times 10^{2} \\
\end{array}$ & $\begin{array}{c}9.7 \\
\times 10^{2}\end{array}$ & $\begin{array}{r}5.0 \\
\times 10^{3}\end{array}$ & $\begin{array}{r}6.1 \\
\times 10^{3}\end{array}$ & $\begin{array}{c}3.9 \\
\times 10\end{array}$ & $\begin{array}{c}1.9 \\
\times 10\end{array}$ & $\begin{array}{c}3.4 \\
\times 10^{2}\end{array}$ & $\begin{array}{r}1.5 \\
\times 10^{4}\end{array}$ \\
\hline Maximum & $\begin{array}{c}6.7 \\
\times 10^{7}\end{array}$ & $\begin{array}{c}2.1 \\
\times 10^{3}\end{array}$ & $\begin{array}{r}2.1 \\
\times 10^{3}\end{array}$ & $\begin{array}{r}8.5 \\
\times 10^{3}\end{array}$ & $\begin{array}{c}1.0 \\
\times 10^{4}\end{array}$ & $\begin{array}{c}8.4 \\
\times 10\end{array}$ & $\begin{array}{c}4.2 \\
\times 10\end{array}$ & $\begin{array}{c}7.5 \\
\times 10^{2}\end{array}$ & $\begin{array}{c}2.7 \\
\times 10^{4}\end{array}$ \\
\hline
\end{tabular}

\begin{tabular}{|c|c|c|c|c|c|c|c|c|}
\hline Doel & ${ }^{3} \mathrm{H}$ & $110 \mathrm{~m}_{\mathrm{Ag}}$ & ${ }^{58} \mathrm{Co}$ & ${ }^{60} \mathrm{Co}$ & ${ }^{51} \mathrm{Cr}$ & ${ }^{134} \mathrm{Cs}$ & ${ }^{137} \mathrm{Cs}$ & ${ }^{54} \mathrm{Mn}$ \\
\hline Average & $4.0 \times 10^{7}$ & $3.9 \times 10^{2}$ & $2.1 \times 10^{3}$ & $7.7 \times 10^{2}$ & $3.0 \times 10$ & $4.6 \times 10^{2}$ & $2.5 \times 10^{3}$ & $1.5 \times 10$ \\
\hline Maximum & $5.4 \times 10^{7}$ & $1.3 \times 10^{3}$ & $9.3 \times 10^{3}$ & $2.4 \times 10^{3}$ & $7.0 \times 10$ & $3.5 \times 10^{3}$ & $9.4 \times 10^{3}$ & $7.4 \times 10$ \\
\hline Doel & $95 \mathrm{Nb}$ & ${ }^{106} \mathrm{Ru}$ & ${ }^{124} \mathrm{Sb}$ & ${ }^{125} \mathrm{Sb}$ & ${ }^{89} \mathrm{Sr}$ & ${ }^{90} \mathrm{Sr}$ & ${ }^{123 m_{m}} \mathrm{Te}$ & $95 \mathrm{Zr}$ \\
\hline Average & $1.9 \times 10$ & $1.8 \times 10$ & $6.2 \times 10^{2}$ & $1.6 \times 10^{3}$ & $1.0 \times 10$ & $3.6 \times 10$ & $1.2 \times 10^{2}$ & 2.9 \\
\hline Maximum & $8.9 \times 10$ & $1.2 \times 10^{2}$ & $2.3 \times 10^{3}$ & $2.5 \times 10^{3}$ & $8.4 \times 10$ & $1.87 \times 10^{2}$ & $3.8 \times 10^{2}$ & $2.2 \times 10$ \\
\hline
\end{tabular}

Tihange, these were ${ }^{55} \mathrm{Fe},{ }^{60} \mathrm{Co},{ }^{95} \mathrm{Nb},{ }^{134} \mathrm{Cs},{ }^{137} \mathrm{Cs},{ }^{89} \mathrm{Sr},{ }^{90} \mathrm{Sr}$ and ${ }^{3} \mathrm{H}$, and 'other radionuclides' consisted of ${ }^{58} \mathrm{Co},{ }^{110 \mathrm{~m}} \mathrm{Ag},{ }^{123 \mathrm{~m}} \mathrm{Te},{ }^{124} \mathrm{Sb}$ and ${ }^{125} \mathrm{Sb}$ (for details see Vandenhove et al., 2009). For Doel, dose and risk assessment was performed for ${ }^{51} \mathrm{Cr},{ }^{54} \mathrm{Mn},{ }^{58} \mathrm{Co},{ }^{60} \mathrm{Co},{ }^{95} \mathrm{Zr},{ }^{110 \mathrm{~m}} \mathrm{Ag},{ }^{123 \mathrm{~m}} \mathrm{Te},{ }^{124} \mathrm{Sb},{ }^{125} \mathrm{Sb},{ }^{134} \mathrm{Cs},{ }^{137} \mathrm{Cs},{ }^{89} \mathrm{Sr}$, ${ }^{90} \mathrm{Sr}$ and ${ }^{3} \mathrm{H}$.

The ecosystems to be evaluated were identified and reference organisms were indicated (Tab. III). For the Tihange NPP, significant terrestrial natural reserves may only be indirectly impacted by the discharges since the Meuse river is 
TABLE III

\begin{tabular}{ll}
$\begin{array}{l}\text { Selected reference organisms for the terrestrial and aquatic ecosystems near the Tihange and } \\
\text { Doel NPPs. Reference organisms written in italic are newly defined reference organisms. }\end{array}$ \\
If reference organisms are underlined they are only considered for the Doel NPP assessment. \\
\hline Reference organisms - Terrestrial ecosystem & Reference organisms - Aquatic ecosystem \\
\hline Soil invertebrate (ICRP Earthworm) & Phytoplankton (FASSET Phytoplankton) \\
Detritivorous invertebrate (FASSET Woodlouse) & $\underline{\text { Phytoplankton (Cyanophycea) }}$ \\
Gastropod (ICRP Snail) & Vascular plant (FASSET Vascular plant) \\
Amphibian (ICRP Frog) & Zooplankton (FASSET Zooplankton) \\
Reptile (FASSET Snake) & Insect larvae (FASSET Insect larvae) \\
Flying insects (ICRP Bee) & Amphibian (ICRP Frog) \\
Lichen \& bryophytes (ICRP Bryophyte) & $\underline{\text { Pelagic invertebrate (e.g. Mysidacea) }}$ \\
Grasses \& herbs (ICRP Wild grass) & Bivalve mollusc (FASSET Bivalve mollusc) \\
Grass roots & Gastropod (FASSET Gastropod) \\
Tree (ICRP Pine tree) & Crustacean (FASSET Crustacean) \\
Shrub/large grasses and herbs & Benthic ${ }^{*}$ fish (FASSET Benthic fish) \\
Mammal (ICRP Rat) & Benthic fish - small (e.g. common goby) \\
Mammal (Rabbit) & Benthic fish - large (e.g. European bass) \\
Mammal (Small mouse) & Pelagic fish (ICRP Salmonid/Trout) \\
Mammal (ICRP Deer) & Pelagic fish - small (e.g. Ninespine stickleback) \\
Bird (ICRP Duck) & Pelagic fish - large (e.g. Atlantic salmon) \\
Large bird (e.g. Greylag goose) & Salmonid egg (fish egg) \\
Small bird (e.g. Meadow pipit) & Bird (ICRP Duck) \\
Bird egg (ICRP Duck egg) & Large bird (e.g. Great Cormorant) \\
Bird egg (Small) & $\underline{\text { Small bird (e.g. Sedge warbler) }}$ \\
\hline &
\end{tabular}

canalised downstream of the Tihange NPP. Only in the unlikely event of extreme flooding or when placing dredged contaminated sediments on the river borders can the natural reserve be potentially impacted. For Doel, the pristine natural reserve 'Verdronken Land van Saeftinghe', a breeding ground for many birds and nursery for fish and shrimp, and located in the tide zone of the Scheldt river, is potentially directly impacted. The characteristics of the reference organisms (habitat, life cycle, geometry, occupation factor) were determined.

\subsection{Exposure and risk assessment}

Concentrations in water and sediments were predicted based on the discharged amounts, river and radionuclide characteristics using the Schaeffer river model (Schaeffer, 1975). The maximum sediment concentrations, obtained for each radionuclide at a different distance from the discharge point, were calculated and 
organisms are conservatively assumed to be exposed simultaneously to these maxima. Terrestrial organisms were considered to be exposed to concentration maxima in dredged sediments disposed of on the river banks.

To estimate the exposure to non-human biota, the EC-ERICA-tool was used (Garnier-Laplace and Gilbin, 2006) and, with the exception of the solid-liquid distribution coefficients, the default parameter values were used to calculate the transfer of the radionuclides from sediment to organism. For the solid-liquid distribution coefficients, values more appropriate for the slightly alkaline conditions of the Meuse and Scheldt rivers were selected. No concentration ratios (CRs) were available for $\mathrm{Cr}$ and $\mathrm{Fe}$ in the ERICA tool and these values were derived from the literature or via similar approaches to derive CR estimates as proposed by Beresford et al. (2007). For the newly defined reference organisms, CR values were mainly derived from homologous reference organisms.

To evaluate the potential impact of the liquid discharges on the ecosystem, the dose rates obtained for the reference organisms were compared with the screening value of $10 \mu \mathrm{Gy} \cdot \mathrm{h}^{-1}$, assumed to protect ecosystems as stated by ERICA (GarnierLaplace and Gilbin, 2006) and PROTECT (Andersson et al., 2008). Potential impact is expressed as a risk quotient $(R Q)$, defined as the ratio of the dose rate and the screening value. If $R Q<1$, the environment is unlikely to be at risk.

\section{Results and discussion}

In a first environmental impact scenario, the liquid discharge limits based on human protection criteria are used to check if these limits are set restrictive enough to also protect the environment. This scenario is a hypothetical scenario since the actual radioactive releases are much lower than the discharge limits. For all risk assessments (Tihange and Doel, aquatic and terrestrial environments) the RQs were below one (Fig. 1).

For the freshwater ecosystem in Tihange, the highest $R Q$ value $(0.085)$ was obtained for 'Insect larvae' (Fig. 1A). Since for all radionuclides the maximum sediment concentrations were used in the assessment (although maxima occurred for the different radionuclides at different distances from the discharge point), it can be concluded with confidence that freshwater ecosystems will not be impacted if liquid discharges at the current discharge limits are released into the environment. Also, for terrestrial ecosystems, all $R Q$ s are far below 1 (the highest value is 0.069 for 'Rat', Fig. 1B). ${ }^{60} \mathrm{Co}$ is the most contributing radionuclide for both ecosystems. Similarly, since it was assumed that terrestrial organisms are exposed to dredged sediments at their concentration maxima, disposed of on the 

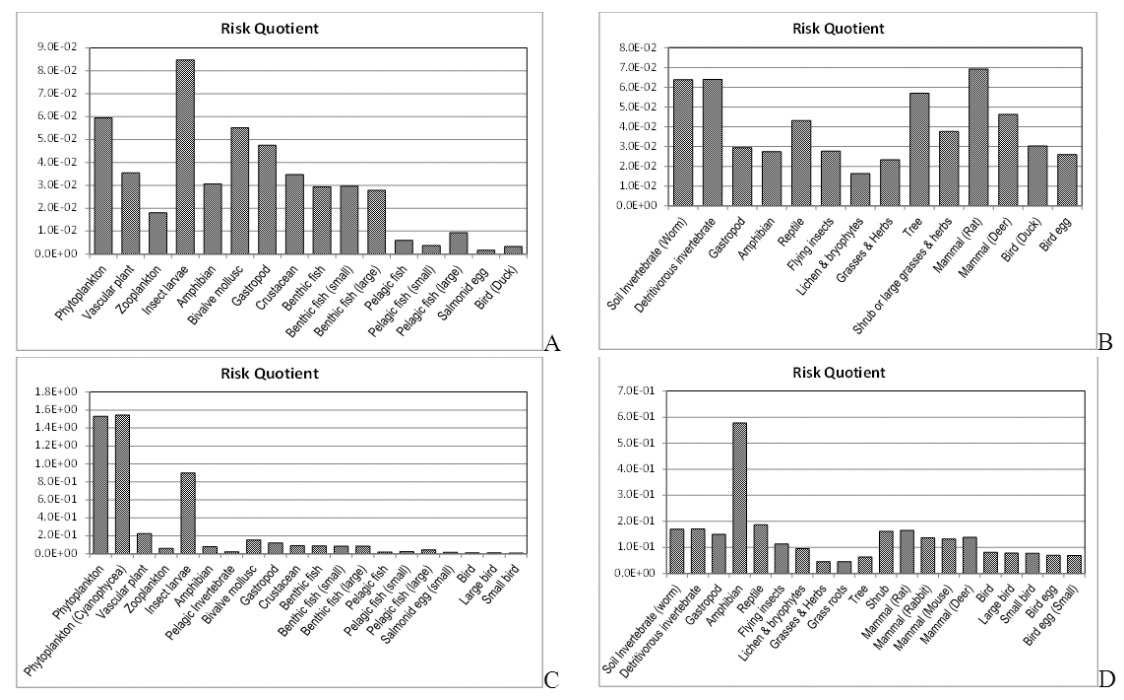

Figure 1 - Risk quotients for selected reference organisms following a Tier 2 risk assessment for the Tihange $(A, B)$ and Doel $(C, D)$ liquid discharge limits for aquatic $(A, C)$ and terrestrial ecosystems $(B, D)$.

river banks, it can be concluded with confidence that the terrestrial environment will not be impacted if liquid discharges set at the current discharge limits are released into the environment.

For freshwater ecosystems in Doel hypothetically impacted by the current liquid discharge limits, the $R Q$ is also lower than 1 for all organisms. The highest $R Q$ s were obtained for phytoplankton and cyanophyceae $(R Q=0.2)$. The radiological risk is almost entirely due to ${ }^{241} \mathrm{Am}$. The ${ }^{241} \mathrm{Am} \mathrm{CR}\left(40000 \mathrm{~kg} . \mathrm{L}^{-1}\right.$ ) for phytoplankton (and for the cyanophyceae a similar value was assumed) is the highest among the reference organisms selected (a factor of 2 higher compared with insect larvae to a factor of 20000 higher compared with birds and pelagic fish). The origin of this CR (Copplestone et al., 2001) is a default R\&D-128 value, of which the origin is ambiguous. Perhaps this CR is overestimated. Furthermore, the discharge limits for the Doel NPP are only set for tritium and other 'alpha, beta and gamma' activity, without specifying the amounts of the different discharged radionuclides necessary to assess the dose rates to non-human biota. Generally for 'alpha, beta and gamma' activity, a repartitioning among the different radionuclides was derived from the isotopic composition for the Tihange NPP discharge limits. Hereby, it was assumed that all alpha activity was composed of ${ }^{241} \mathrm{Am}$. This is a conservative assumption given that the dose conversion 
coefficients (DCCs) for ${ }^{241} \mathrm{Am}$ are among the highest. Discharges are unlikely to contain ${ }^{241} \mathrm{Am}$ since discharges monitored over a 10 -year period did not reveal the presence of ${ }^{241} \mathrm{Am}$ (or any other alpha emitter). We may hence deduce that radiological releases at the liquid discharge limits will unlikely to have a negative impact on the aquatic ecosystems of the Scheldt rivers river. For terrestrial ecosystems potentially impacted by the release limits of the Doel NPP, the highest $R Q\left(0.16,{ }^{137} \mathrm{Cs}\right.$ most contributing) was obtained for 'Rat' (Fig. 1D).

Based on these results, it can be concluded that the liquid radiological discharge limits for the Belgian NPPs are set at a level at which no harm to the aquatic and terrestrial environments of the Meuse and Scheldt rivers is expected.

In a second series of assessments, the potential risk for the aquatic and terrestrial environments of the Meuse and Scheldt rivers from the actual releases (maxima and averages over the last ten years) was assessed. The more conservative ERICA assessments using maximum environmental media concentrations predicted with the Schaeffer river model resulted in predicted dose rates of three orders of magnitude below the screening value of $10 \mu \mathrm{Gy} \cdot \mathrm{h}^{-1}$. The highest $R Q$ s were obtained for 'Insect larvae' (0.002) and 'Soil invertebrate, Detritivorous invertebrate, Rat' (0.003) for the Tihange freshwater and terrestrial
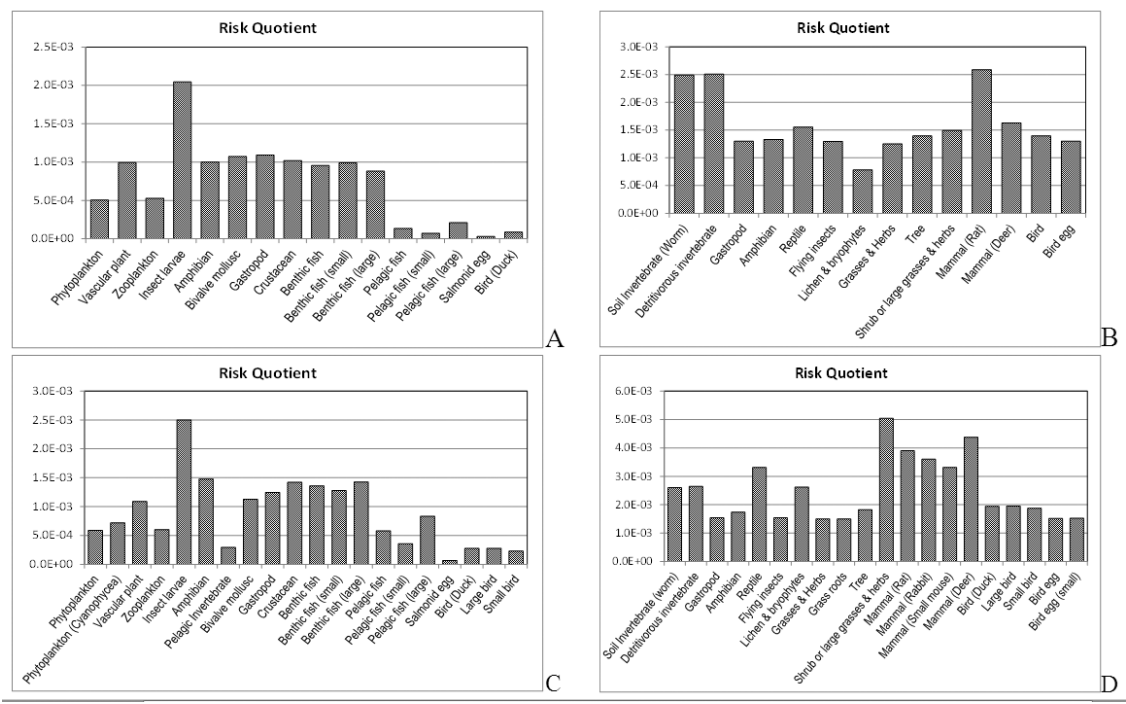

Figure 2 - Risk quotients for selected reference organisms following a Tier 2 risk assessment for the Tihange (A, B) and Doel (C, D) actual discharge maxima (1999-2008) for aquatic $(A, C)$ and terrestrial ecosystems $(B, D)$. 
ecosystems, respectively (Figs. $2 \mathrm{~A}$ and $2 \mathrm{~B}$ ), with ${ }^{60} \mathrm{Co}$ the most contributing radionuclide. For Doel, the highest $R Q$ s were obtained for 'Insect larvae' $(0.003$, ${ }^{58} \mathrm{Co}$ most contributing) and 'Shrub' $\left(0.005,{ }^{137} \mathrm{Cs}\right.$ most contributing) for the freshwater and terrestrial ecosystems, respectively (Figs. 2C and 2D). $R Q$ s for the more realistic predictions of environmental media concentrations, using the tenyear discharge averages, are a few-fold lower than those predicted for the release maxima. Actual liquid radiological discharges are hence considered to have no impact on the aquatic and terrestrial ecosystems of the Meuse and Scheldt rivers.

\section{Conclusions}

For the discharge limits (set to protect man), all $R Q$ s were below one. It could hence be concluded that the liquid radiological discharge limits for the Belgian NPPs are set stringently enough not to harm the aquatic and terrestrial environments of the Meuse and Scheldt rivers. Since for the different radionuclides considered, actual discharges are up to 4 orders of magnitude lower than discharge limits, the $R Q$ s obtained are $<<1$ and the freshwater and terrestrial environments of the Meuse and Scheldt rivers are expected not to be harmed by the actual liquid discharges from the Belgian NPPs.

It should be noted that there is significant uncertainty involved in the environmental transfer modeling and consequently the Environmental Risk Assessment performed. Assumptions concerning the source term composition were made. Furthermore, for many input parameters, in particular the concentration ratios, data are scarce or even unavailable and various methods were used to derive best estimate parameter values. However, for realistic (to some extent still conservative) assessment scenarios, the estimated dose rates to freshwater and terrestrial organisms were three orders of magnitude below the screening value of $10 \mu \mathrm{Gy} \cdot \mathrm{h}^{-1}$ at which the ecosystem is assumed not to be affected. Therefore, we can assume that it is very unlikely that the freshwater and terrestrial ecosystems of the Scheldt and Meuse rivers are affected by the routine liquid discharges from the Belgian NPPs.

Acknowledgements. This study was performed on behalf of GDF-SUEZ, under the GDF SUEZ/SCK・CEN agreement framework.

\section{REFERENCES}

Andersson P., Beaugelin-Seiller K., Beresford N.A., Copplestone D., Della Vedova C., GarnierLaplace J., Howard B.J., Howe P., Oughton D.H., Wells C., Whitehouse P. (2008) Numerical benchmarks for protecting biota from radiation in the environment: proposed levels and underlying reasoning and recommendations. Protect. Protection of the Environment from Ionising Radiation in a Regulatory Context, Deliverable 5b, EC-project N ${ }^{\circ}$ FI6R-036425. 
Beresford N., Brown J., Copplestone D., Garnier-Laplace J., Howard B., Larsson C.M., Oughton D., Pröhl G., Zinger I. (Eds) (2007) D-ERICA: An integrated approach to the assessment and management of environmental risks from ionising radiation: Description of purpose, methodology and application. EC-project FI6R-CT-2004-508847, 2007, p. 88.

Copplestone D., Bielby S., Jones S.R., Patton D., Daniel P., Gize I. (2001) Impact Assessment of Ionising Radiation on Wildlife, R\&D Publication 128, (Environment Agency, Bristol), ISBN: $185705590 \mathrm{X}$.

EC (2003) Technical Guidance Document on Risk Assessment, in support of Commission Directive 93/67/EEC on Risk Assessment for new notified substances, Commission Regulation (EC) No 1488/94 on Risk assessment for existing substances, Directive 98/8/EC of the European Parliament and of the Council concerning the placing of biocidal products on the market. Part II. EUR 20418 EN/2. IHCP (Office for Official Publication of the European Communities, Luxemburg).

Environment Canada (1997) Environmental assessments of the priority substances under the Canadian environmental protection act. Guidance manual version 1.0. EPS 2/CC/3E., Chemicals Evaluation Division, Commercial Chemicals Evaluation Branch (Environment Canada, 1997).

Garnier-Laplace J., Gilbin R. (2006) Derivation of predicted no effect dose rate values for ecosystems (and their sub-organisational levels) exposed to radioactive substances. Deliverable D5. European Commission, 6th Framework, Contract N ${ }^{\circ}$ FI6RCT-2003-508847.

IAEA (1992) Effects of ionizing radiation on plants and animals at levels implied by current radiation protection standards, Technical Reports Series 332 (IAEA, Vienna).

ICRP Publication 91 (2003) A framework for assessing the impact of ionising radiation on non-human species, Ann. ICRP 33, 3.

ICRP Publication 103 (2007) The 2007 Recommendations of the international commission on radiological protection, Ann. ICRP 37, 2-4, 1-332.

Schaeffer R. (1975) Conséquences du déplacement des sédiments sur la dispersion des radionucléides, in: Proceedings of the Conference on Impacts of nuclear releases into the aquatic environment, 30 June-4 July, Otaniemi, Finland, IAEA, IAEA-SM 198/4, 1975, p. 263.

UNSCEAR (1996) Sources and effects of ionizing radiation. Report to the general assembly, with scientific annex. (UNSCEAR, United Nations, New York).

US DOE (US Department of Energy) (2002) A graded approach for evaluating radiation doses to aquatic and terrestrial biota. Technical Standard DOE-STD-1153-2002. Washington DC, USA.

Vandenhove H., Sweeck L., Van Hees M., Wannijn J. (2009) Evaluation method for the environmental risk associated with radioactive liquid discharges from the Belgian nuclear power plants of Doel and Tihange: Principles, equations and parameters, SCK $\cdot$ CEN-ER-131 (SCK•CEN, Mol, Belgium), p. 53. 